\title{
Corrosion Inhibition of 1,4-di (1-vinyl-3-methylimidazolium) Benzene Dibromide on Mild Steel in HCl Solution
}

\author{
Ayssar Nahlé, ${ }^{*}$ Reem Saeed Al-tuniji, Ideisan Abu-Abdoun \\ and Ibrahim Abdel-Rahman \\ Department of Chemistry, College of Sciences, University of Sharjah, Sharjah, P.O.Box: 27272, \\ United Arab Emirates
}

Received 10 April 2016; accepted 28 April 2016

\begin{abstract}
The inhibition and the effect of temperature and concentration of 1,4-di(1-vinyl-3methylimidazolium) benzene dibromide (VMIBB) on the corrosion of mild steel in 1.0 $\mathrm{M} \mathrm{HCl}$ solution was investigated by electrochemical polarization and weight loss experiments at temperatures ranging from 303 to $343 \mathrm{~K}$. The studied inhibitor concentrations ranged between $1.0 \times 10^{-6} \mathrm{M}$ and $1.0 \times 10^{-2} \mathrm{M}$. The percentage inhibition increased with the increase of the inhibitor's concentration. The percentage inhibition has reached about $93 \%$ at the concentration of $1 \times 10^{-2} \mathrm{M}$ and $303 \mathrm{~K}$. On the other hand, the percentage inhibition decreased with the increase of temperature. Using the Langmuir adsorption isotherm, the thermodynamic parameters for the adsorption of this inhibitor on the metal surface were calculated. 1,4-di(1-vinyl-3-methylimidazolium) benzene dibromide was found to be a potential corrosion inhibitor, since it contained not only nitrogen, but also three aromatic systems, double bond, and it is a large molecule which has a big surface with high malar surface coverage.
\end{abstract}

Keywords: Corrosion, inhibitor, 1,4-di(1-vinyl-3-methylimidazolium) benzene dibromide, Langmuir adsorption isotherm.

\section{Introduction}

In many civil services and industries, corrosion of metals constitutes a serious economic problem. Corrosion leads to an increase in running costs, a decrease in plant efficiency, and affects the product quality. In order to protect the metal from corrosion, inhibitors are used especially when the metal is in contact with aggressive solutions, such as during acid pickling. Prior to coating by electroplating, galvanizing, or painting techniques, the metal has to go through a treatment which requires the removal of scale and salts from steel surfaces, tanks, and pipelines. In order to prevent an extensive dissolution of the underlying metal, the acid must be treated by the addition of organic inhibitors which will

\footnotetext{
* Corresponding author. E-mail address: anahle@ sharjah.ac.ae
} 
adsorb onto the metal/solution interface by displacing water molecules on the surface and forming a compact barrier film.

Most organic corrosion inhibitors consist of organic compounds containing polar groups by which the molecule can strongly adsorb onto the metal surface $[1,2]$.

The presence of the inhibitor on the metal surface decreases the reaction rate at the metal/solution interface, as it acts as a catalytic poison without being involved in the reaction. Such inhibitors contain organic N, P, S, and $\mathrm{OH}$ groups. Corrosion inhibition of mild steel in acidic solutions has been widely investigated. Various nitrogen-containing compounds have been used as corrosion inhibitors by several authors. These inhibitors include quaternary ammonium salts [3-10], polyamino-benzoquinone polymers [11], azoles [12], substituted aniline-N-salicylidenes [13], amides [14], heterocyclic compounds $[15,16]$, and cationic surfactants $[17,18]$. Sulfur-containing inhibitors were also investigated by other authors [19-24]. The effect of ions addition, such as iodide [26], and chloride [27] on the inhibition efficiency of some organic compounds were studied by others. The structural effect of organic compounds as corrosion inhibitors was also studied [28, 29]. In all these studies, the nitrogen atom(s) in the compounds showed to be able to adsorb very well onto the metal surface, and form a protective layer, which, in its turn, increased the corrosion inhibition with the increase in the concentration of the inhibitor, in some cases reaching $99 \%$ inhibition [30].

No studies have been found on 1,4-di(1-vinyl-3-methylimidazolium) benzene dibromide (VMIBB) (Scheme 1) as a corrosion inhibitor for mild steel in $1.0 \mathrm{M}$ $\mathrm{HCl}$ solution. In our studies, mild steel was chosen, because high temperature aggressive acids are widely used in industries in connection to mild and low alloy steels. Because of their environmentally friendly characteristics, in addition to their unique properties, imidazolium salts are expected to be good corrosion inhibitors [31-33].

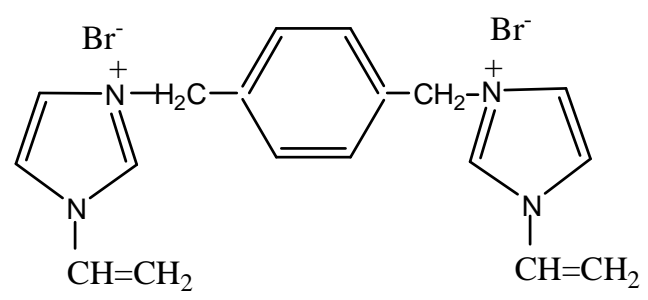

Scheme 1. 1,4-di(1-vinyl- 3-methylimidazolium) benzene dibromide.

\section{Experimental details}

\section{Synthesis of 1,4-di(1-vinyl-3-methylimidazolium) benzene dibromide}

1,4-di(1-vinyl-3-methylimidazolium) benzene dibromide salt (3) was prepared by refluxing two molar equivalent from vinylimidazole (1) with one molar equivalent from 1,4-dibromethybenzene (2) in acetone, as shown in the procedure below (Scheme 2):

A mixture of 6.20 grams $(0.066 \mathrm{~mol})$ of vinylimidazole $(1)$, and 8.72 grams of 1,4 dibromethylbenzene $(0.033 \mathrm{~mol})(2)$, in $500 \mathrm{~mL}$ carbon tetrachloride 
$\left(\mathrm{CCl}_{4}\right)$ was refluxed for 6 hours. After cooling to room temperature, a crystalline off-white precipitate (3) was collected by filtration, then washed with excess diethyl ether and dried. Dissolution in small amount of chloroform and addition of excess diethyl ether gave the pure salt (3) in 80 percent yield with a melting point between 133 and $136^{\circ} \mathrm{C}$.

2<smiles>C=Cn1ccnc1</smiles>

(1)

(2)

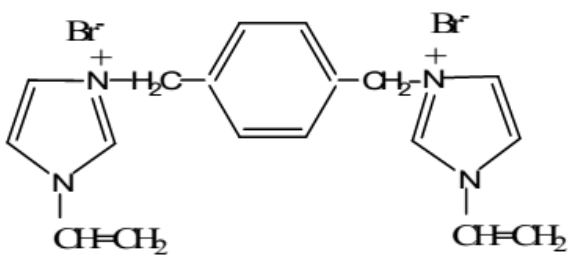

(3)

Scheme 2. Synthesis of 1,4-di(1-vinyl-3-methylimidazolium) benzene dibromide.

\section{Electrochemistry}

\section{Electrode preparation}

A $5 \mathrm{~mm}$ diameter piece cut from a mild steel rod (IS 226 containing $0.18 \% \mathrm{C}$, $0.6 \% \mathrm{Mn}$, and $0.35 \% \mathrm{Si}$ ) supplied by "Reliable Steel Traders", Sharjah, UAE, formed the working electrode; and was mounted, using Araldite epoxy resin, in a glass tube that fits in the electrochemical cell. Prior to each experiment, the working mild steel electrode was abraded using a series of carborundum papers starting with 600 grades and ending with 1200 grades. The electrode surface was then polished with $0.3-\mu \mathrm{m}$ alumina on cloth, washed with deionized distilled water, and rinsed with pure ethanol, before being transferred to the electrochemical cell that contained deaerated fresh electrolyte.

\section{Instrumentation}

Fig. 1 shows the electrochemical cell which consisted of a mild steel working electrode (WE), a saturated calomel electrode (SCE) as a reference electrode (RE), and platinum gauze counter electrode (CE). Prior to each experiment, nitrogen was bubbled to deaerate the electrolyte. This cell was designed in a way that the nitrogen was allowed to escape into the solution, precluding its collection at the electrode surface.

The counter-electrode compartment was separated from the working-electrode compartment with a glass frit in order to protect the working electrode from any substance that may be produced at the counter electrode during the electrochemical reactions. The following electrochemical instrument was used:

A PC controlled AUTOLAB PGSTAT128N Modular Potentiostat (electrochemical workstation) (supplied from Metrohm) capable of driving currents up to $\pm 800 \mathrm{~mA}$ with an output potential across the cell of up to $\pm 10 \mathrm{~V}$.

\section{Measuring procedure}

Electrochemical corrosion measurements (Tafel plots) were carried out on the mild steel electrode, prepared as described before, in $1.0 \mathrm{M} \mathrm{HCl}$ and in $1.0 \mathrm{M}$ $\mathrm{HCl}$ containing various concentrations of the prepared VMIBB inhibitor. The concentration of the inhibitor ranged from $1 \times 10^{-6} \mathrm{M}$ to $1 \times 10^{-2} \mathrm{M}$. 


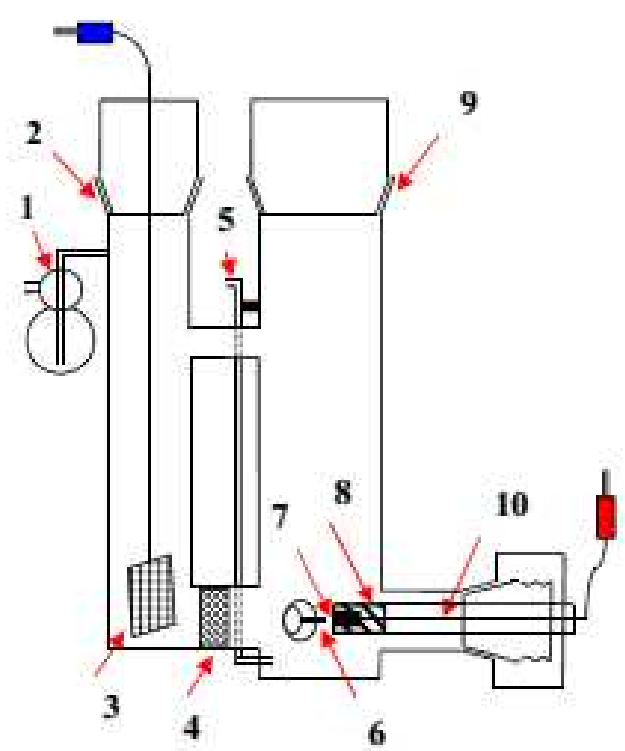

Figure 1. The electrochemical cell. 1) gas bubbler, 2) B 12 glass socket, 3) Platinum gauze (counter electrode), 4) glass frit, 5) inlet for nitrogen gas, 6) luggin capillary (reference electrode), 7) iron rod (working electrode), 8) epoxy resin, 9) B 24 glass socket, 10) copper wire.

After filling the cell with $60 \mathrm{~mL}$ of the electrolyte, the solution was deaerated with nitrogen gas, and the WE equilibrium potential was monitored and recorded vs. SCE, until it reached a steady state. The electrode potential was then scanned between overpotentials of $-100 \mathrm{mV}$ to $+100 \mathrm{mV}$ vs. SCE at a sweep rate of 1 $\mathrm{mV} \cdot \mathrm{s}^{-1}$.

\section{Results and discussions}

The anodic and cathodic polarization curves (Tafel plot) of the mild steel electrode in deaerated $1.0 \mathrm{M} \mathrm{HCl}$ solution, with and without the addition of various concentrations of 1,4-di(1-vinyl-3-methylimidazolium) benzene dibromide (VMIBB), are shown in Fig. 2.

Both the anodic and cathodic branches of the curve were affected by the presence of the inhibitor. The corrosion current decreased with the increase of the concentration of VMIBB inhibitor, as shown in Table 1. In the absence of the inhibitor (in $1.0 \mathrm{M} \mathrm{HCl}$ ), the corrosion current was found to be $0.84 \mathrm{~mA}$, which decreased sharply to $0.038 \mathrm{~mA}$ at $1 \times 10^{-2} \mathrm{M}$ of VMIBB inhibitor in $1.0 \mathrm{M} \mathrm{HCl}$ (reaching about $95 \%$ inhibition) (Table 1$)$.

The values of the percentage inhibition of VMIBB at various concentrations in 1.0 $\mathrm{M} \mathrm{HCl}$ were calculated according to the following equation and the results and are shown in Table 1:

$$
\text { Percentage inhibition }=\frac{\left.\left(\mathrm{I}_{\mathrm{Corr}}\right)_{\text {Uninh }_{n}}-\mathrm{O}_{\mathrm{Corr}_{2}}\right)_{\text {inh }}}{\left.\mathrm{O}_{\mathrm{Corr}}\right)_{\text {Uninh }}} \times 100
$$

where: $\left(I_{\text {Corr. }}\right)_{\text {Uninh. }}$ is the corrosion current in the uninhibited solution, and $\left(I_{\text {Corr. }}\right)_{I n h .}$ is the corrosion current in inhibited solution. 


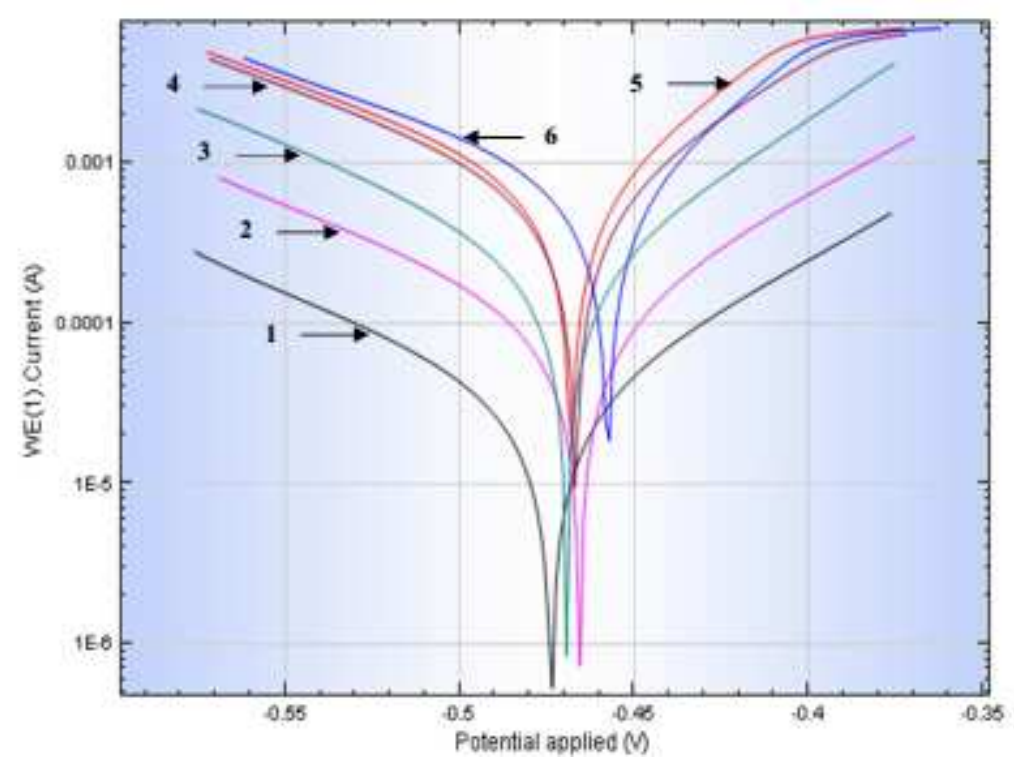

Figure 2. Anodic and cathodic polarization curves of mild steel in an uninhibited $1.0 \mathrm{M}$ $\mathrm{HCl}$ solution and in $1.0 \mathrm{M} \mathrm{HCl}$ containing various concentrations of 1,4-di(1-vinyl-3methylimidazolium) benzene dibromide. 1) $1.0 \mathrm{M} \mathrm{HCl}+10^{-2} \mathrm{M}$ Inhibitor; 2) $1.0 \mathrm{M}$ $\mathrm{HCl}+10^{-3} \mathrm{M}$ Inhibitor;3) $1.0 \mathrm{M} \mathrm{HCl}+10^{-4} \mathrm{M}$ Inhibitor; 4) $1.0 \mathrm{M} \mathrm{HCl}+10^{-5} \mathrm{M}$ Inhibitor; 5) $1.0 \mathrm{M} \mathrm{HCl}+10^{-6} \mathrm{M}$ Inhibitor; 6) $1.0 \mathrm{M} \mathrm{HCl}$.

Table 1 shows that the percentage inhibition increases gradually from about $1 \%$ (with $1 \times 10^{-6} \mathrm{M}$ inhibitor) to reach about $95 \%$ with $1 \times 10^{-2} \mathrm{M}$ inhibitor.

Table 1. Tafel corrosion currents and percent inhibitions of 1,4-di(1-vinyl-3methylimidazolium) benzene dibromide at various concentrations in $1.0 \mathrm{M} \mathrm{HCl}$ at room temperature.

\begin{tabular}{|c|c|c|c|c|c|c|}
\hline & $\begin{array}{c}1.0 \mathrm{M} \\
\mathrm{HCl}\end{array}$ & $\begin{array}{c}1.0 \mathrm{M} \\
\mathrm{HCl}+ \\
\text { 1x10-6 M }^{-6} \\
\text { VMIBB }\end{array}$ & $\begin{array}{c}1.0 \mathrm{M} \\
\mathrm{HCl}+ \\
\text { 1x10 }^{-5} \mathrm{M} \\
\text { VMIBB } \\
\end{array}$ & $\begin{array}{c}1.0 \mathrm{M} \\
\mathrm{HCl}+ \\
1 \times 10^{-4} \mathrm{M} \\
\text { VMIBB } \\
\end{array}$ & $\begin{array}{c}1.0 \mathrm{M} \\
\mathrm{HCl}+ \\
1 \times 10^{-3} \mathrm{M} \\
\text { VMIBB } \\
\end{array}$ & $\begin{array}{c}1.0 \mathrm{M} \\
\mathrm{HCl}+ \\
1 \times 10^{-2} \mathrm{M} \\
\text { VMIBB }\end{array}$ \\
\hline $\begin{array}{c}\mathbf{I}_{\text {corrosion }} \\
/ \mathbf{m A}\end{array}$ & 0.84 & 0.83 & 0.73 & 0.25 & 0.12 & 0.04 \\
\hline $\begin{array}{c}\text { Percent } \\
\text { Inhibition }\end{array}$ & - & 1.19 & 12.00 & 70.24 & 85.71 & 95.24 \\
\hline
\end{tabular}

\section{Effect of temperature}

\section{Specimen preparation}

Rectangular specimens $(1 \mathrm{~cm} \times 2.3 \mathrm{~cm} \times 0.3 \mathrm{~cm})$ cut from a large sheet of $3 \mathrm{~mm}$ thick mild steel (IS 226 containing $0.18 \% \mathrm{C}, 0.6 \% \mathrm{Mn}$, and $0.35 \% \mathrm{Si}$ ), supplied by "Reliable Steel Traders", Sharjah, UAE; were used for weight loss measurements. A 2-mm diameter hole was drilled close to the upper edge of the specimen, and served to be hooked with a glass rod for immersion purposes. Prior to each experiment, the specimens were polished with 600 grade emery paper, rinsed with distilled water, degreased with acetone, dried, and finally weighed precisely on an accurate analytical balance. 


\section{Instrumentation}

For the weight-loss measurements, a $250 \mathrm{~mL}$ round bottom flask fitted with a reflux condenser and long glass rod, which served to hook and immerse the specimen and in turn immersed in a thermally controlled water bath, was used.

\section{Measuring procedure}

The flask was filled with $100 \mathrm{~mL}$ of $1.0 \mathrm{M} \mathrm{HCl}$ solution with and without (VMIBB) of various concentrations, then placed in water bath. As soon as the required working temperature was reached, the mild steel sample was immersed in the solution, and left there for exactly six hours, after which the sample was removed, rinsed with distilled deionized water, degreased with acetone, dried, and finally weighed precisely on an accurate analytical balance. This procedure was repeated with all the samples, with a variety of inhibitor concentrations ranging from $1 \times 10^{-6} \mathrm{M}$ up to $1 \times 10^{-2} \mathrm{M}$; and at temperatures ranging from 303 to $343 \mathrm{~K}$. These experiments were repealed for reproducibility, and the average values were reported.

\section{Results and discussions (effect of temperature)}

Weight loss corrosion tests were carried out on the mild steel in $1.0 \mathrm{M} \mathrm{HCl}$ in the absence and presence of (VMIBB) over a period of 6 hours. Table 2 represents the corrosion rates $\left[\mathrm{mg} \cdot \mathrm{cm}^{-2} \cdot \mathrm{h}^{-1}\right]$, and the percentage efficiencies [\%] for the studied inhibitor with concentrations varying from $1 \times 10^{-6} \mathrm{M}$ to $1 \times 10^{-2} \mathrm{M}$ at 303 , $313,323,333$, and $343 \mathrm{~K}$, respectively. The percentage efficiency was calculated according to the following expression:

$$
\% \text { Inhibition }=\frac{\mathrm{CR}_{\text {Uninh }}-\mathrm{CR}_{\text {inh }}}{\mathrm{CR}_{\text {Uninh }} .} \times 100
$$

where $C R_{\text {Uninh. }}$ and $C R_{I n h .}$ are the corrosion rate without and with inhibitor, respectively.

Table 2. Effect of concentration of 1,4-di(1-vinyl-3-methylimidazolium) benzene dibromide on the corrosion rate $\left(\mathrm{mg} \cdot \mathrm{cm}^{-2} \cdot \mathrm{h}^{-1}\right)$ and percentage efficiency of mild steel in $1.0 \mathrm{M} \mathrm{HCl}$ at various temperatures.

\begin{tabular}{|c|c|c|c|c|c|c|c|c|c|c|}
\hline \multirow[b]{3}{*}{$\begin{array}{c}\text { Concentration } \\
\text { of } \\
\text { Inhibitor }\end{array}$} & \multicolumn{10}{|c|}{ Temperature / K } \\
\hline & \multicolumn{2}{|c|}{303} & \multicolumn{2}{|c|}{313} & \multicolumn{2}{|c|}{$\mathbf{3 2 3}$} & \multicolumn{2}{|c|}{333} & \multicolumn{2}{|c|}{343} \\
\hline & $\begin{array}{l}\text { Corr. } \\
\text { Rate }\end{array}$ & $\begin{array}{c}\% \\
\text { Eff. }\end{array}$ & $\begin{array}{l}\text { Corr. } \\
\text { Rate }\end{array}$ & $\begin{array}{c}\% \\
\text { Eff. }\end{array}$ & $\begin{array}{l}\text { Corr. } \\
\text { Rate }\end{array}$ & $\begin{array}{c}\% \\
\text { Eff. }\end{array}$ & $\begin{array}{l}\text { Corr. } \\
\text { Rate }\end{array}$ & $\begin{array}{c}\% \\
\text { Eff. }\end{array}$ & $\begin{array}{l}\text { Corr. } \\
\text { Rate }\end{array}$ & $\begin{array}{c}\% \\
\text { Eff. }\end{array}$ \\
\hline $1.0 \mathrm{M} \mathrm{HCl}$ & 0.414 & - & 976 & - & 234 & - & 605 & - & 9.36 & - \\
\hline $\begin{array}{l}1.0 \mathrm{M} \mathrm{HCl}+ \\
1 \times 10^{-6} \mathrm{M}\end{array}$ & 0.327 & 21.01 & 0.792 & 18.87 & 2.042 & 8.59 & 5.157 & 8.00 & 8.66 & 7.54 \\
\hline $\begin{array}{c}1.0 \mathrm{M} \mathrm{HCl}+ \\
1 \times 10^{-5} \mathrm{M} \\
\end{array}$ & 222 & 46.28 & 588 & 39.82 & 1.438 & 35.61 & 3.920 & 30.07 & 6.74 & 28.01 \\
\hline $\begin{array}{c}1.0 \mathrm{M} \mathrm{HCl}+ \\
1 \times 10^{-4} \mathrm{M}\end{array}$ & 94 & 74.82 & 183 & 81.26 & 0.367 & 83.55 & 1.208 & 78.44 & 2.86 & 69.47 \\
\hline $\begin{array}{c}1.0 \mathrm{M} \mathrm{HCl}+ \\
1 \times 10^{-3} \mathrm{M}\end{array}$ & 036 & 91.38 & 0.098 & 89.96 & 0.154 & 93.09 & 0.331 & 94.09 & 0.74 & 92.13 \\
\hline $\begin{array}{c}1.0 \mathrm{M} \mathrm{HCl}+ \\
1 \mathbf{x 1 0}^{-2} \mathrm{M}\end{array}$ & 0.026 & 93.72 & 0.081 & 91.70 & 0.118 & 94.73 & 0.267 & 95.24 & 0.36 & 96.19 \\
\hline
\end{tabular}


Fig. 3 and Fig. 4 show the plots of the corrosion rate of (VMIBB) as a function of concentration at 303, 313, 323, 333, and $343 \mathrm{~K}$. At $303 \mathrm{~K}$ (Fig. 3) the corrosion rate dropped from $0.414 \mathrm{mg} \cdot \mathrm{cm}^{-2} \cdot \mathrm{h}^{-1}(1.0 \mathrm{M} \mathrm{HCl}$ in the absence of the inhibitor) to $0.327 \mathrm{mg} \cdot \mathrm{cm}^{-2} \cdot \mathrm{h}^{-1}$, when $1 \times 10^{-6} \mathrm{M}$ of (VMIBB) was present in the $1.0 \mathrm{M} \mathrm{HCl}$. This corrosion rate continued to decrease slightly to reach $0.222 \mathrm{mg} \cdot \mathrm{cm}^{-2} \cdot \mathrm{h}^{-1}$ (46.3\% inhibition) at a concentration of $1 \times 10^{-5} \mathrm{M}$, followed by a further slow decrease to reach $0.104 \mathrm{mg} \cdot \mathrm{cm}^{-2} \cdot \mathrm{h}^{-1}$, when the inhibitor's concentration was $1 \times 10^{-4} \mathrm{M}$; and kept on decreasing to reach $0.026 \mathrm{mg} \cdot \mathrm{cm}^{-2} \cdot \mathrm{h}^{-1}$ (93.7\% inhibition) at a concentration of $1 \times 10^{-2} \mathrm{M}$. At $313 \mathrm{~K}$ (Fig. 3), the curve showed a steep decrease in corrosion rate between $1 \times 10^{-6} \mathrm{M}$ and $1 \times 10^{-4} \mathrm{M}$, followed by a slow decrease to form a plateau between $1 \times 10^{-3} \mathrm{M}$ and $1 \times 10^{-2} \mathrm{M}$, where the inhibition reached about $92 \%$.

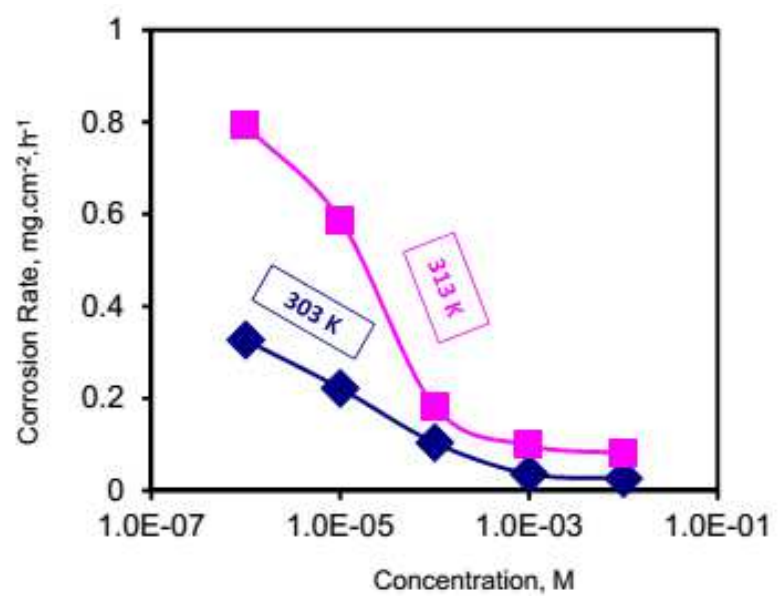

Figure 3. Effect of concentration of 1,4-di(1-vinyl-3-methylimidazolium) benzene dibromide on the corrosion rate $\left(\mathrm{mg} \cdot \mathrm{cm}^{-2} \cdot \mathrm{h}^{-1}\right)$ of mild steel in $1.0 \mathrm{M} \mathrm{HCl}$ at various temperatures. $(\diamond 303 \mathrm{~K} ; \mathbf{\square} 313 \mathrm{~K})$.

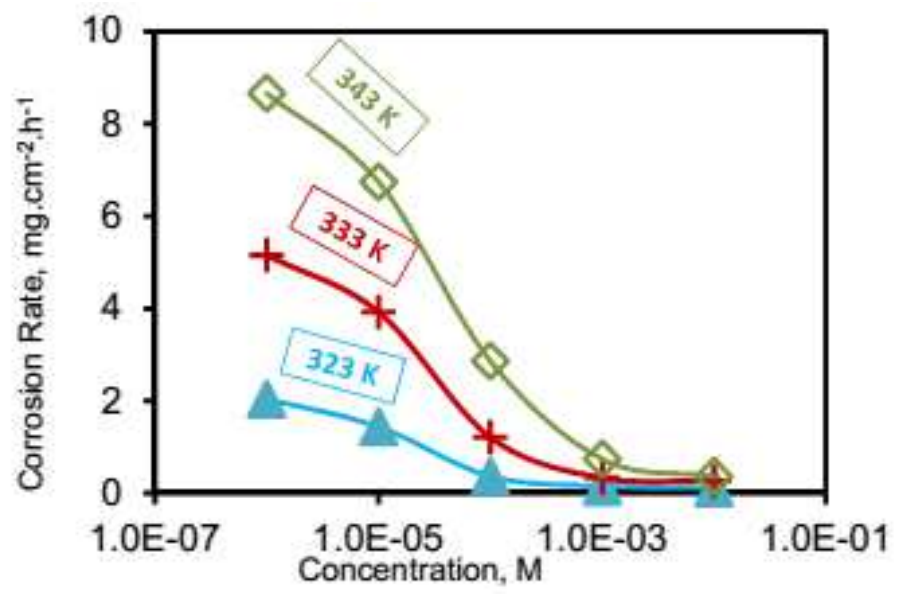

Figure 4. Effect of concentration of 1,4-di(1-vinyl-3-methylimidazolium) benzene dibromide on the corrosion rate $\left(\mathrm{mg} . \mathrm{cm}^{-2} \cdot \mathrm{h}^{-1}\right)$ of mild steel in $1.0 \mathrm{M} \mathrm{HCl}$ at various temperatures: ( $\boldsymbol{\Delta} 323 \mathrm{~K}$; $+333 \mathrm{~K} ; \diamond 343 \mathrm{~K})$.

At $323 \mathrm{~K}$ (Fig. 4), a slow decrease in the corrosion current occurred between $1 \times 10^{-6} \mathrm{M}$ and $1 \times 10^{-4} \mathrm{M}$ and remained steady at higher concentrations to reach $0.118 \mathrm{mg} \cdot \mathrm{cm}^{-2} \cdot \mathrm{h}^{-1}$ at $1 \times 10^{-2} \mathrm{M}$. 
At 333 and $343 \mathrm{~K}$ (Fig. 5) the presence of the (VMIBB) inhibitor caused a sharp decrease in the corrosion rate between $1 \times 10^{-6} \mathrm{M}$ and $1 \times 10^{-4} \mathrm{M}$, followed by a slow decrease at higher concentrations, reaching $0.267 \mathrm{mg} \cdot \mathrm{cm}^{-2} \cdot \mathrm{h}^{-1}(95.24 \%$ inhibition), and $0.36 \mathrm{mg} \cdot \mathrm{cm}^{-2} \cdot \mathrm{h}^{-1}$ (96.19\% inhibition) for $1 \times 10^{-2} \mathrm{M}$ inhibitor employed at $333 \mathrm{~K}$ and $343 \mathrm{~K}$, respectively.

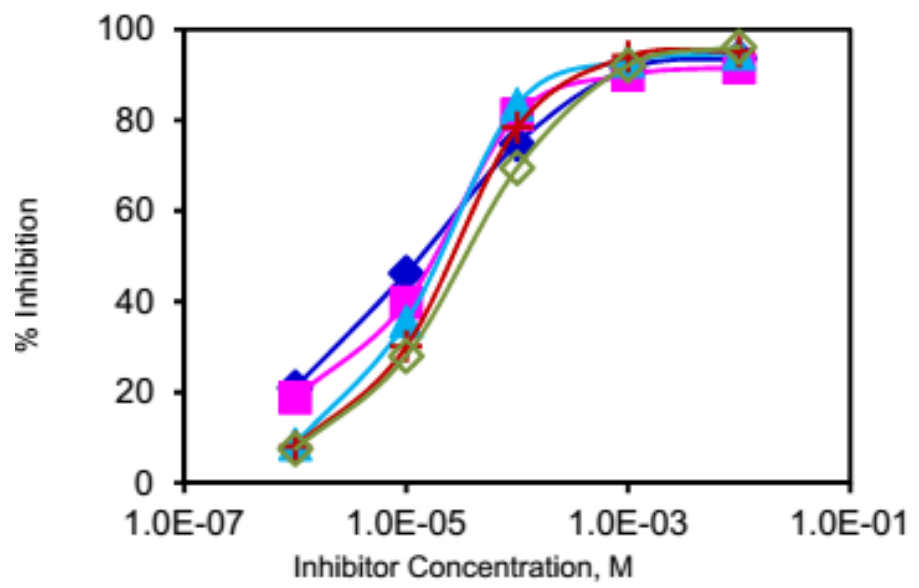

Figure 5. Effect of concentration of 1,4-di(1-vinyl-3-methylimidazolium) benzene dibromide on the percent inhibition of mild steel in $1.0 \mathrm{M} \mathrm{HCl}$ at various temperatures. $(\diamond 303 \mathrm{~K} ; \boldsymbol{\square} 313 \mathrm{~K} ; \boldsymbol{\Delta} 323 \mathrm{~K} ;+333 \mathrm{~K} ; \diamond 343 \mathrm{~K})$.

The data obtained from the weight loss measurements were plotted in accordance to Arrhenius equation:

$$
\text { In rate }=-\frac{E_{\mathrm{a}}}{R T}+\text { const. }
$$

where $\mathrm{E}_{\mathrm{a}}$ is the activation energy $\left[\mathrm{kcal}^{\mathrm{m}} \mathrm{mol}^{-1}\right], \mathrm{R}$ is the gas constant $\left[\mathrm{kcal}^{\mathrm{m}} \mathrm{mol}^{-1}\right.$ ], $\mathrm{T}$ is the temperature $[\mathrm{K}]$, and const. $=$ constant.

The Arrhenius plots of the corrosion of mild steel in $1.0 \mathrm{M} \mathrm{HCl}$ solution (Ln corrosion rate as a function of $1 / \mathrm{T}$ ) (Table 3), with and without the presence of (VMIBB) at concentrations ranging from $1 \times 10^{-6} \mathrm{M}$ to $1 \times 10^{-2} \mathrm{M}$, are presented in Fig. 6.

Table 3. Data obtained from the weight loss measurements for Arrhenius equation: (1/T) against Ln corrosion rate.

\begin{tabular}{|c|c|c|c|c|c|c|}
\hline \multirow{2}{*}{$\begin{array}{l}(1 / T) \mathbf{T} \\
10^{3} K^{-1}\end{array}$} & \multicolumn{6}{|c|}{ Ln corrosion rate $\left(\mathrm{mg}^{2} \mathrm{~cm}^{-2} \cdot \mathrm{h}^{-1}\right)$} \\
\hline & $\begin{array}{c}1.0 \mathrm{M} \\
\mathrm{HCl}\end{array}$ & $\begin{array}{l}1.0 \mathrm{M} \mathrm{HCl} \\
+1 \times 10^{-2} \mathrm{M} \\
\end{array}$ & $\begin{array}{l}1.0 \mathrm{M} \mathrm{HCl} \\
+1 \times 10^{-3} \mathrm{M}\end{array}$ & $\begin{array}{l}1.0 \mathrm{M} \mathrm{HCl} \\
+1 \times 10^{-4} \mathrm{M} \\
\end{array}$ & $\begin{array}{l}1.0 \mathrm{M} \mathrm{HCl} \\
+1 \times 10^{-5} \mathrm{M} \\
\end{array}$ & $\begin{array}{l}1.0 \mathrm{M} \mathrm{HCl} \\
+1 \times 10^{-6} \mathrm{M} \\
\end{array}$ \\
\hline 3.30 & -0.882 & -3.650 & -3.324 & -2.263 & -1.505 & -1.118 \\
\hline 3.19 & -0.024 & -2.513 & -2.323 & -1.698 & -0.531 & -0.233 \\
\hline 3.10 & 0.804 & -2.137 & -1.871 & -1.002 & 0.363 & 0.714 \\
\hline 3.00 & 1.724 & -1.321 & -1.106 & 0.189 & 1.366 & 1.640 \\
\hline 2.92 & 2.236 & -1.022 & -0.301 & 1.051 & 1.908 & 2.159 \\
\hline
\end{tabular}


From Fig. 6, the slope $\left(-\frac{E_{a}}{R}\right)$ of each individual line was determined and used to calculate the activation energy according to equation 2 , and taking $\mathrm{R}=1.987 \times 10^{-3}$ kcal.mol ${ }^{-1}$ (Table 4). In the presence of high inhibitor concentrations $\left(1 \times 10^{-2} \mathrm{M}\right.$ and $1 \times 10^{-3} \mathrm{M}$ ), caused a decrease in the activation energy (initially 16.52 kcal.mol ${ }^{-1}$ ), which could be attributed to chemisorption due to charge sharing or transfer from the organic inhibitor to the metal surface to form coordinate covalent bonds, while an increase in the activation energy, occurred at low concentrations of the inhibitor $\left(1 \times 10^{-4} \mathrm{M}\right.$ to $\left.1 \times 10^{-6} \mathrm{M}\right)$, is due to physisorption [34].

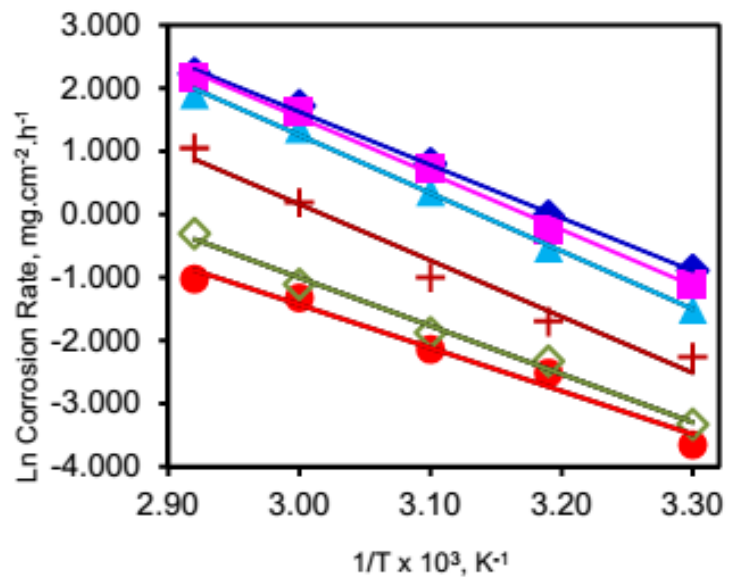

Figure 6. Effect of temperature on the corrosion rate of mild steel in $1.0 \mathrm{M} \mathrm{HCl}$ solution with and without the presence of various concentrations of 1,4-di(1-vinyl-3methylimidazolium) benzene dibromide. ( $1 \mathrm{M} \mathrm{HCl} ; \boldsymbol{\square} 1 \times 10^{-7} \mathrm{M} ; \boldsymbol{\Delta} 1 \times 10^{-6} \mathrm{M} ; \boldsymbol{+}$ $\left.1 \times 10^{-5} \mathrm{M} ; \diamond 1 \times 10^{-4} \mathrm{M} ; \bigcirc 1 \times 10^{-3} \mathrm{M}\right)$.

Table 4. Activation energy $\left(\mathrm{E}_{\mathrm{a}}\right)$ for the corrosion of mild steel in $1.0 \mathrm{M} \mathrm{HCl}$ with and without 1,4-di(1-vinyl-3-methylimidazolium) benzene dibromide inhibitor at various concentrations.

\begin{tabular}{|c|c|c|c|c|c|}
\hline \multirow{2}{*}{ System } & \multicolumn{5}{|c|}{ 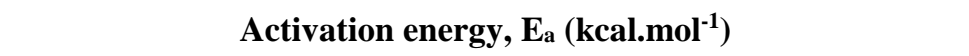 } \\
\hline & $1 \times 10^{-2} \mathrm{M}$ & $1 \times 10^{-3} \mathrm{M}$ & $1 \times 10^{-4} M$ & $1 \times 10^{-5} \mathrm{M}$ & $1 \times 10^{-6} \mathrm{M}$ \\
\hline $1.0 \mathrm{M} \mathrm{HCl}$ & 16.52 & 16.52 & 16.52 & 16.52 & 16.52 \\
\hline $\begin{array}{l}\text { 1.0 M HCl + 1,4-di(1-vinyl- } \\
\text { 3-methylimidazolium) } \\
\text { benzene dibromide }\end{array}$ & 13.35 & 15.03 & 17.49 & 20.37 & 21.44 \\
\hline
\end{tabular}

The surface coverage of various concentrations of (VMIBB) (ranging from $1 \times 10^{-6} \mathrm{M}$ to $1 \times 10^{-2} \mathrm{M}$ ) on mild steel surface as a function of temperature are shown in Table 5.

The dependence of the fraction $\mathrm{C}_{\mathrm{inh}} / \theta$ as a function of $\mathrm{C}_{\mathrm{inh}}$ of (VMIBB) is shown in Fig. 7. The obtained plot of the inhibitor is almost linear, with a correlation coefficient about 1.00 .

The plot of $\frac{C_{i n h}}{\theta}$ versus $C_{\text {inh }}$ yielded a straight line with nearly unit slope and the best fits are obtained with Langmuir adsorption isotherm, as presented in Fig. 7. It was found that the linear correlation coefficient is very close to 1.000 , which 
clearly proves that the adsorption of (VMIBB) from 1.0 M hydrochloric acid solutions on mild steel obeys the Langmuir adsorption isotherm, which is described by the following equation:

$$
\frac{C_{i n h}}{\theta}=C_{i n h}+\frac{1}{K_{a d s}}
$$

where $\theta$ is the degree of coverage, $\mathrm{K}_{\mathrm{ads}}$ is the equilibrium constant for the adsorption reaction, and $\mathrm{C}_{\mathrm{inh}}$ is the concentration of the inhibitor.

Table 5. Effect of concentration of 1,4-di(1-vinyl-3-methylimidazolium) benzene dibromide on surface coverage, $\theta$, for mild steel in $1.0 \mathrm{M} \mathrm{HCl}$ at various temperatures.

\begin{tabular}{|c|c|c|c|c|c|}
\hline & \multicolumn{5}{|c|}{ Temperature / K } \\
\hline & 303 & 313 & 323 & 333 & 343 \\
\hline $\begin{array}{c}\text { Concentration } \\
\text { of inhibitor }\end{array}$ & $\theta$ & $\theta$ & $\theta$ & $\theta$ & $\theta$ \\
\hline $1.0 \mathrm{M} \mathrm{HCl}+1 \times 10^{-6} \mathrm{M}$ & 0.210 & 0.189 & 0.086 & 0.080 & 0.075 \\
\hline $1.0 \mathrm{M} \mathrm{HCl}+1 \times 10^{-5} \mathrm{M}$ & 0.463 & 0.399 & 0.356 & 0.310 & 0.280 \\
\hline $1.0 \mathrm{M} \mathrm{HCl}+1 \times 10^{-4} \mathrm{M}$ & 0.748 & 0.813 & 0.836 & 0.784 & 0.695 \\
\hline $1.0 \mathrm{M} \mathrm{HCl}+1 \times 10^{-3} \mathrm{M}$ & 0.914 & 0.800 & 0.931 & 0.941 & 0.921 \\
\hline $1.0 \mathrm{M} \mathrm{HCl}+1 \times 10^{-2} \mathrm{M}$ & 0.937 & 0.917 & 0.947 & 0.952 & 0.962 \\
\hline
\end{tabular}

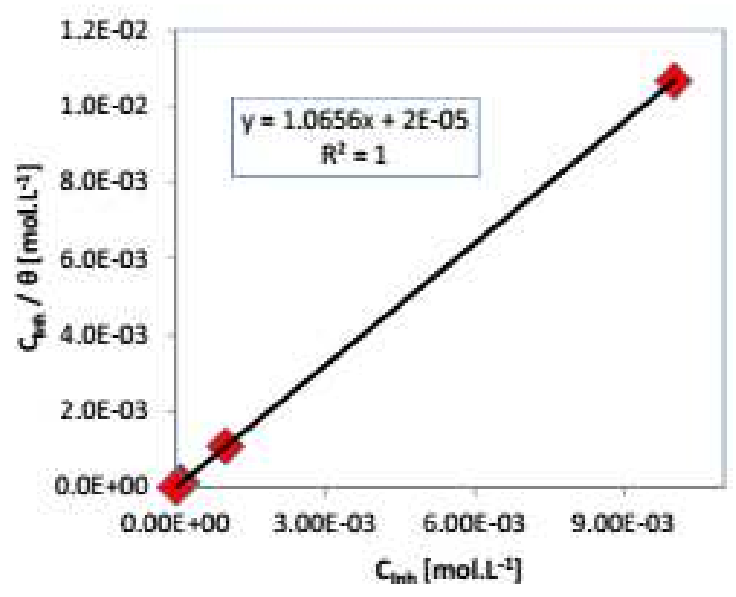

Figure 7. Langmuir isotherm for the adsorption of 1,4-di(1-vinyl-3 methylimidazolium) benzene dibromide on mild steel in $1.0 \mathrm{M} \mathrm{HCl}$.

From the intercept of the straight line $\left(\frac{C_{i n h}}{\theta}\right)=\mathrm{f}\left(C_{\overline{i n h}}\right), \mathrm{k}_{\mathrm{ads}}$ value can be calculated.

The equilibrium constant for the adsorption reaction, $\mathrm{K}$, is related to the standard free energy of adsorption via the following equation:

$$
K_{v q}=\frac{1}{\mathrm{Es}_{\mathrm{s}} \mathrm{E}} \mathrm{e}^{\left(-\frac{\Delta \mathrm{G}}{\mathrm{RT}}\right)}
$$

where $K_{\text {eq }}$ is the equilibrium constant for the adsorption reaction, $\Delta G$ is the standard free energy [ $\left.\mathrm{kcal}^{\mathrm{mol}}{ }^{-1}\right], \mathrm{R}$ is the gas constant $\left[\mathrm{kcal}^{\mathrm{mol}}{ }^{-1}\right]$, and $\mathrm{T}$ is the absolute temperature $[\mathrm{K}]$. 
Rearrangement of (Equation 5) leads to Equation 9.

$$
\begin{aligned}
& 55.5 \mathrm{~K}_{\mathrm{eq}}=\mathrm{e}^{\left(-\frac{\Delta G}{\mathrm{RT}}\right)} \\
& \ln \left(55.5 \mathrm{~K}_{\mathrm{eq}}\right)=\ln \mathrm{e}^{\left(-\frac{\Delta \mathrm{G}}{\mathrm{RT}}\right)} \\
& \ln \left(55.5 \mathrm{~K}_{\mathrm{eq}}\right)=-\frac{\Delta \mathrm{G}}{\mathrm{RT}} \\
& \Delta \mathrm{G}=-\mathrm{RT} \ln \left(55.5 \mathrm{~K}_{\mathrm{eq}}\right)
\end{aligned}
$$

The standard free energy change of adsorption of the inhibitor, $\Delta G^{0}$, can be calculated from the results in Figure 7 used to calculate the equilibrium constant, $\mathrm{K}_{\mathrm{eq}}$, and Equation 14 at various temperatures (303 to $343 \mathrm{~K}$ ).

The standard enthalpy change of adsorption, $\Delta \mathrm{H}^{0}$, for the inhibitor can be calculated from the following equation:

$$
\Delta \mathrm{H}^{\circ}=\mathrm{E}_{\mathrm{a}}-\mathrm{RT}
$$

The entropy, $\Delta \mathrm{S}^{0}$, can be calculated at various temperatures for the inhibitor using Equation 16:

$$
\Delta \mathrm{G}^{0}=\Delta \mathrm{H}^{0}-\mathrm{T} \Delta \mathrm{S}^{0}
$$

Tables 6,7 and 8 show the thermodynamic data obtained in the presence of the inhibitor at $1 \times 10^{-2} \mathrm{M}$. These thermodynamic quantities represent the algebraic sum of the values for adsorption and desorption. The negative value of $\Delta \mathrm{G}^{0}$ (Table 6) indicates the spontaneous adsorption of inhibitor on the surface of the mild steel. The calculated standard free energy, $\Delta G^{0}$, varied from -12.39 kcal.mol ${ }^{-1}$ at $303 \mathrm{~K}$ to $-13.26 \mathrm{kcal}^{\mathrm{mol}} \mathrm{m}^{-1}$ at $343 \mathrm{~K}$.

Table 6. Free energy of adsorption $\left(\Delta \mathrm{G}_{\mathrm{ads}}\right)$ for mild steel in $1.0 \mathrm{M} \mathrm{HCl}$ in the presence of 1,4-di(1-vinyl-3-methylimidazolium) benzene dibromide at various temperatures $(303 \mathrm{~K}-343 \mathrm{~K})$.

\begin{tabular}{|c|c|c|c|c|}
\hline \multicolumn{5}{|c|}{$\Delta \mathbf{G}$, kcal.mol $^{-1}$} \\
\hline $\mathbf{3 0 3} \mathbf{~ K}$ & $\mathbf{3 1 3 ~ K}$ & $\mathbf{3 2 3 ~ K}$ & $\mathbf{3 3 3 ~ K}$ & $\mathbf{3 4 3} \mathbf{~ K}$ \\
\hline-8.93 & -9.23 & -9.52 & -9.82 & -10.11 \\
\hline
\end{tabular}

The standard enthalpy change of adsorption for the inhibitor, $\Delta \mathrm{H}^{0}$, is shown in Table 7. The positive values of the $\Delta \mathrm{H}$ are due to the fact that, in order for the inhibitor to get adsorbed on the metal substrate (adsorption process is exothermic, negative enthalpy), water molecules which are already adsorbed on the surface have to get desorbed into the solution (desorption process is endothermic, positive enthalpy). Since an enormous number of water molecules were initially adsorbed on the metal surface, a large amount of energy is provided to achieve this endothermic process; on the other hand, a small number of inhibitor molecules will replace the water at the metal surface, which, in its turn, will release a small amount of energy during this adsorption process. 
Table 7. Enthalpy of adsorption $(\Delta \mathrm{H})$ for mild steel in $1.0 \mathrm{M} \mathrm{HCl}$ in the presence of $1 \times 10^{-2}$ M 1,4-di(1-vinyl-3-methylimidazolium) benzene dibromide at various temperatures $(303 \mathrm{~K}-343 \mathrm{~K})$.

\begin{tabular}{|c|c|c|c|c|}
\hline \multicolumn{5}{|c|}{$\Delta$ H, kcal.mol-1 } \\
\hline $\mathbf{3 0 3} \mathbf{~ K}$ & $\mathbf{3 1 3} \mathbf{~ K}$ & $\mathbf{3 2 3} \mathbf{~ K}$ & $\mathbf{3 3 3} \mathbf{~ K}$ & $\mathbf{3 4 3} \mathbf{~ K}$ \\
\hline 12.75 & 12.73 & 12.71 & 12.69 & 12.67 \\
\hline
\end{tabular}

The adsorption process is exothermic and associated with a decrease in entropy $(\Delta \mathrm{S})$ of solute, while the opposite is true for the solvent. The gain in entropy which accompanies the substitutional adsorption process is attributed to the increase in the solvent entropy (Table 8). This agrees with the general suggestion that the values of $\Delta \mathrm{G}^{0}$ increase with the increase of inhibition efficiency [22,35], as the adsorption of the organic compound is accompanied by desorption of water molecules off the surface.

Table 8. Change in entropy $(\Delta \mathrm{S})$ for mild steel in $1.0 \mathrm{M} \mathrm{HCl}$ in the presence of 1,4di(1-vinyl-3-methylimidazolium) benzene dibromide at various temperatures (303 K $343 \mathrm{~K})$.

\begin{tabular}{|c|c|c|c|c|}
\hline \multicolumn{5}{|c|}{$\Delta \mathbf{S}$, kcal. $^{-1} \cdot$ mol $^{-1}$} \\
\hline $303 \mathbf{~ K}$ & $\mathbf{3 1 3 ~ K}$ & $\mathbf{3 2 3} \mathbf{~ K}$ & $\mathbf{3 3 3 ~ K}$ & $\mathbf{3 4 3} \mathbf{~ K}$ \\
\hline 0.072 & 0.070 & 0.069 & 0.068 & 0.066 \\
\hline
\end{tabular}

The high inhibition efficiency may be attributed to the preferred flat orientation of this compound on the metal surface. The interaction occurs between the delocalized $\pi$-electrons of the three aromatic rings, the two double bonds $(-\mathrm{C}=$ $\mathrm{C}-$ ), and the lone pair of electrons on $\mathrm{N}$ atoms with the positively charged metal surface. In addition, the two double bonds $(-\mathrm{C}=\mathrm{C}-)$ play a major role in the stabilization of both sides of the inhibitor on the surface of the metal.

\section{Conclusions}

1,4-di(1-vinyl-3-methylimidazolium) benzene dibromide was found to be a very efficient inhibitor for mild steel in $1.0 \mathrm{M} \mathrm{HCl}$ solution, reaching about 94 per cent at a considerably low concentration $\left(1 \times 10^{-2} \mathrm{M}\right)$ at $303 \mathrm{~K}$. The results obtained from electrochemical and weight loss measurements are in mutual agreement.

(VMIBB) is a potential corrosion inhibitor, since it contains not only a nitrogen atom, but also three phenyl rings. It was apparent from the molecular structure that this compound would be adsorbed onto the metal surface through the lone pair of electrons of nitrogen and p-electrons of the three aromatic rings, as well as the two double bonds that are attached to the imidazole rings. The percentage inhibition in the presence of this inhibitor decreased with the increase of temperature at low concentrations $1 \times 10^{-6} \mathrm{M}$ to $1 \times 10^{-4} \mathrm{M}$, which indicated that physical adsorption was the predominant inhibition mechanism. However, the percentage inhibition in the presence of this inhibitor was not affected with 
temperature at high concentrations $\left(1 \times 10^{-3} \mathrm{M}\right.$ and $\left.1 \times 10^{-2} \mathrm{M}\right)$, which indicates a chemical adsorption on the surface of the metal.

\section{References}

1. Damaskin BB, Pietrii OA, Batrokov WW. Adsorpcja organiczeskich sojedinienij na electrodach. Moskva; 1968.

2. Okamato G, Nagayama M, Kato J, et al. Effect of organic inhibitors on the polarization characteristics of mild steel in $\mathrm{HCl}$ solution. Corrosion Sci. 1962;2:21.

3. Beloglazov SM, Dzhafarov ZI, Polyakov VN, et al. Quaternary ammonium salts as corrosion inhibitors of steel in the presence of sulfate-reducing bacteria. Protection Metals USSR. 1991;27:810.

4. Fokin AV, Pospelov MV, Levichev AN. Structural and protective capacities of organic corrosion inhibitors. 2. Alkylethylene diamines and quaternary ammonium salts. Protection Metals USSR. 1983;19:242.

5. Nahlé A. Electrochemical studies of corrosion inhibition of a series of quaternary ammonium salts for iron in $\mathrm{HCl}$ solution. Corrosion Prevent Control. 1997;44:99.

6. Nahlé A. Inhibition of iron in $\mathrm{HCl}$ using benzyl trimethyl and triethyl ammonium chloride. Corrosion Prevent Control. 1998;45:124.

7. Nahlé A. Effect of triethanolamine on the electrochemical dissolution of solder in $\mathrm{NaOH}$ solution. Bull Electrochem. 2002;18:105.

8. Nahlé A, Walsh FC. Electrochemical studies of two corrosion inhibitors for iron in $\mathrm{HCl}$ : cetyltrimethylammonium bromide and tetraphenylphosphonium chloride. Corrosion Prevent Control. 1995;42:30.

9. Savithri BV, Mayanna SM. Tetrabutyl ammonium iodide, cetyl pyridinium bromide and cetyl trimethyl ammonium bromide as corrosion inhibitors for mild steel in sulfuric acid. Ind J Chem Technol. 1996;3:256.

10. Vasudevant T, Muralidharan S, Alwarappan S, et al. The influence of Nhexadecyl benzyl dimethyl ammonium chloride on the corrosion of mild steel in acids. Corrosion Sci. 1995;37:1235.

11. Muralidharan S, Phani KLN, Pitchumani S, et al. Polyamino-benzoquinone polymers - a new class of corrosion inhibitors for mild steel. J Electrochem Soc. $1995 ; 142: 1478$.

12. Popova A. Temperature effect on mild steel corrosion in acid media in presence of azoles. Corrosion Sci. 2007;49:2144.

13. Talati JD, Desai MN, Shah NK. Meta-Substituted aniline-N-salicylidenes as corrosion inhibitors for zinc in sulfuric acid. Mater Chem Phys. 2005;93:54.

14. Tüken T, Yazici B, Erbil M. Turk J Chem. 2002;26:735.

15. Fattah AA, Mabrouk EM, Abd El-Gulil RM, et al. N-Heterocyclic compounds as corrosion inhibitors for zinc in hydrochloric acid solutions. Bull Soc Chimique France. 1991;1:48.

16. Granese SL, Rosales BM, Oviedo C, et al. The inhibition action of heterocyclic nitrogen organic compounds on $\mathrm{Fe}$ and steel in $\mathrm{HCl}$ media. Corrosion Sci. 1992;33:1439. 
17. Al-Lohedan HA, Khamis E, Issa ZA. Studies on the influence of temperature on the adsorption of some cationic surfactants on to steel. Adsorption Sci Technol. 1996;13:137.

18. Qiu LG, Xie AJ, Shen YH. A novel diazole-based cationic Gemini surfactant: Synthesis and effect on corrosion inhibition of carbon-steel in hydrochloric acid. Mater Chem Phys. 2005;91:269.

19. Ateya BC, El-Anadouli BE, El-Nizamy FM. The effect of thiourea on the corrosion kinetics of mild steel in $\mathrm{H}_{2} \mathrm{SO}_{4}$. Corrosion Sci. 2005;24:497.

20. Nahle A. Effect of temperature on the corrosion inhibition of carbon steel in $\mathrm{HCl}$ solutions. Bull Electrochem. 2001;17: 221.

21. Nahlé A. Inhibition of corrosion of iron in $\mathrm{HCl}$ solution by semicarbazides and Thiosemicarbazides. Bull Electrochem. 2005;21:275.

22. Fouda AS, Mousa MN, Taha FI, et al. The role of some thiosemicarbazide derivatives in the corrosion inhibition of aluminum in $\mathrm{HCl}$. Corrosion Sci. 1986;26:719.

23. Raicheva SN, Aleksiev BV, Sokolova EI. The effect of the chemical structure of some nitrogen-containing and sulphur-containing organic compounds on their corrosion inhibiting action. Corrosion Sci. 1993;34:343.

24. Sanad SH, Ismail AA, El-Meligi AA. The effect of temperature on the corrosion and corrosion inhibition of steel alloys in hydrochloric acid solutions. Bull Electrochem. 1995;11:462.

25. Zucchi F, Trabanelli G, Brunoro G. The influence of chromium content on the inhibitive efficiency of some organic compounds. Corrosion Sci. 1992;33:1135.

26. Huang YL, Goa CN, Lu M, et al. Inhibition effect of $\mathrm{I}^{-}$and $\mathrm{I}_{2}$ on stresscorrosion cracking of stainless steel in acidic chloride solutions. Corrosion. 1993;49:644.

27. Yamaguchi M, Nishihara H. The inhibitive effect of organic cations on passive film breakdown of iron in a chlorine containing borate buffer solution. Corrosion Sci. 1994;36:1133.

28. Kobayashi K, Shimizu K, Iida M. Structural effects of organic compounds as corrosion inhibitors for hydrogen entry into iron in sulfuric acid. Corrosion Sci. 1993;35:1431.

29. Skryler LD, Streltsova EA, Skryleva TL. Hydrocarbon chain length and their effect on corrosion inhibition by alkylammonium chlorides. Protection Metals USSR. 1991;27:755.

30. Nahlé A, Abu-Abdoun I, Abdel-Rahman I. Electrochemical studies of the effect of trans-4-hydroxy-4'-stilbazole on corrosion inhibition of mild steel in $\mathrm{HCl}$ solution. Anti-Corrosion Methods Mater. 2007;54:244.

31. Popova A, Christov M, Vasilev A. Mono- and dicationic benzothiazolic quaternary ammonium bromides as mild steel corrosion inhibitors. Part III: Influence of temperature on the inhibition process. Corrosion Sci. 2015;94:70. 
32. Nahlé A, Abu-Abdoun I, Abdel-Rahman I. Inhibition of Carbon Steel Corrosion by 4-Vinylbenzyl Triphenyl Phosphonium Chloride in $\mathrm{HCl}$ Solution. Anti-Corrosion Methods Mater. 2008;55:217.

33. Zhao H. Innovative applications of ionic liquids as "green" engineering liquids. Chem Eng Comm. 2006;193:1660.

34. Popova A, Christov M, Deligeorgiev T. Influence of the molecular structure on the inhibitor properties of benzimidazole derivatives on mild steel corrosion in $1 \mathrm{M}$ hydrochloric acid. Corrosion. 2003;59:756.

35. Fouda AS, El-Aal AA, Kandil AB. The effect of some phthalimide derivatives on the corrosion behaviour of copper in nitric acid. Anti-Corros Methods Mater. 2005;52:96. 